\title{
INVESTIGATION OF SHALLOW FOUNDATION SOIL BEARING CAPACITY AND SETTLEMENT CHARACTERISTICS OF MINNA CITY CENTRE DEVELOPMENT SITE USING PLAXIS 2D SOFTWARE AND EMPIRICAL FORMULATIONS
}

\author{
A. B. Salahudeen ${ }^{1, *}$ and J. A. Sadeeq ${ }^{2}$ \\ 1 Samaru College of Agriculture, Div. of Agric. College, Ahmadu Bello Univ., Zaria, Kaduna State, NigERIA. \\ 2 Department of Civil Engineering, Ahmadu Bello University, Zaria, Kaduna State, NigERIA. \\ E-mail addresses:1 basalahudeen@gmail.com, 2jasadeeq@yahoo.com
}

\begin{abstract}
This study investigated the soil bearing capacity and foundation settlement characteristics of Minna City Centre development site using standard penetration test (SPT) data obtained from10 SPT boreholes at 0.6, 2.1 and $3.6 \mathrm{~m}$ depths to correlate soil properties. Evaluation of foundation bearing capacity and settlement characteristics for geotechnical preliminary design of foundations was carried out using some conventional empirical/analytical models and numerical modelling. The aim was to investigate and determine the geotechnical parameters required for adequate design of Physical structures of the proposed Minna City Centre, at Minna the capital of Niger state. The SPT N-values were corrected to the standard average energy of $60 \%$ (N60) before the soil properties were evaluated. Using the corrected $N$ values, allowable bearing pressure and elastic settlement of shallow foundations were predicted at $50 \mathrm{kN} / \mathrm{m}^{2}$ applied foundation pressure. The numerical analysis results using Plaxis $2 D$, a finite element code, shows the analytical/empirical methods of estimating the allowable bearing pressure and settlements of shallow foundations that provided acceptable results. Results obtained show that an average bearing capacity value of $100-250 \mathrm{kN} / \mathrm{m}^{2}$ can be used for shallow foundations with embedment of 0.6 to $3.6 \mathrm{~m}$ on the site.
\end{abstract}

Keywords: Bearing capacity, Foundation settlement, Standard Penetration Test, Numerical modelling, Plaxis 2D, Finite element method

\section{INTRODUCTION}

Some Nigerian soils are problematic and adversely affect foundations of structures there by compromise the stability of the structures. These soil problems have resulted to excessive settlement, tilting and collapse of many buildings not only in Nigeria but also around the world [1 - 4].Numerical modelling method that better represents soil constitutive behaviour is required to develop an improved approximation of foundation soil bearing capacity and settlement. Also, there is need to investigate and determine the most appropriate methods that are most suitable to Nigerian soil peculiarities and distinctions based on SPT results, being the most common and economical geotechnical field test used in Nigeria. The study focused on the prediction of foundation soil bearing capacity and settlement based on Standard Penetration Test (SPT) N-values using empirical/analytical (deterministic) models and Plaxis 2D numerical modelling in the proposed Minna City Centre, at Minna the capital of Niger state of the Federal Republic of Nigeria.
Niger State is covered by two major rock formations, the sedimentary and basement complex rocks. Minna occupies the central portion of the Nigerian basement complex. The Minna area comprises of met sedimentary and meta-igneous rocks which have undergone polyphase deformation and metamorphism. These rocks have been intruded by granitic rocks of Pan-African age. Five lithostratigraphic units have been recognized in Minna area: The schist which occur as a flat laying narrow southwest-northeast belt at the central part of Minna with small quartzite ridge parallel to it, the gneiss occur as a small suites at the northern and southern part of the area forming a contact with the granite. Feldspathic rich pegmatite is bounded to the east, with average width of 65 meters and 100 meters long, the pegmatite host tourmaline. Granitic rocks dominate the rock types in the area and vary in texture and composition [2].

When a soil is subjected to an increase in compressive stress due to foundation load, the resulting soil compression is known as settlement of the foundation

\footnotetext{
* Corresponding author, tel: +234-909-068-9549
} 
[5].In many parts of the world, Standard Penetration Test (SPT) is still considered one of the most common in situ tests used to evaluate the strength of coarse grained soils [6]. Bowles [7] stated that $85-90 \%$ of conventional foundation design in North and South America is made using SPT results. SPT data have been used in correlations for unit weight, relative density, angle of internal friction and unconfined compressive strength [8].

The numerical analysis of foundation settlement and bearing capacity were performed using Plaxis 2D, a nonlinear finite element software. Plaxis 2D is used for twodimensional analysis of deformation and stability in geotechnical engineering. It uses advanced soil constitutive models for the simulation of the non-linear, time dependent and anisotropic behaviour of soils and rocks. The input data in Plaxis 2D are index, elastic and strength parameters, obtained from the processed SPT $\mathrm{N}$-values. It generates the unstructured 2D finite element meshes with options of global and local mesh refinements. Using its calculation facilities, Plaxis 2D undergoes a calculation process and presents the calculation and model outputs which can be accessed in animation and/or numerical forms.

The objectives of this research was to estimate the bearing capacity and settlement of foundation soils from measured penetration resistance in terms of the SPT corrected $\mathrm{N}$-values, to evaluate design equations for foundation settlements and bearing capacity using different constitutive models based on SPT results, to model foundation settlement numerically using PLAXIS 2D software and compare the results of the empirical/analytical methods with those of numerical analysis in order to identify the best analytical methods that could be used for the prediction of foundation settlements and bearing capacity in Nigeria considering her peculiar soil properties.

\section{RESEARCH METHODS}

\subsection{Data and Analysis}

The research made use of standard penetration test (SPT) data (using Donut hammer type) collected from 10 test holes (30 data set) distributed over the study area. Bearing capacity and foundation settlement estimations were made at depths of $0.6,2.1$ and $3.6 \mathrm{~m}$ and settlement was determined at applied foundation pressure of 50 $\mathrm{kN} / \mathrm{m}^{2}$.Based on empirical/analytical methods, bearing capacity and settlement were evaluated using some most commonly used models presented in Tables 1 and 2 of the Appendix.

\subsubsection{Bearing capacity}

For the allowable bearing pressures of shallow foundations, footing plan dimensions of $2 \mathrm{~m}$ by $2 \mathrm{~m}$ by
$0.4 \mathrm{~m}$ for length, breadth and depth, respectively were assumed with safety factor of 3 .

\subsubsection{Elastic Settlement of Foundations}

For the elastic settlement of shallow foundations, plan dimensions of $2 \mathrm{~m}$ by $2 \mathrm{~m}$ by $0.4 \mathrm{~m}$ for length, breadth and depth respectively were assumed.

\subsection{Standard Penetration Test}

The SPT was conducted in accordance with ASTM D1586-99 [9]. The standard split tube sampler has an inside diameter of $34.93 \mathrm{~mm}$ and an outside diameter of $50.8 \mathrm{~mm}$. The numbers of blows required for a spoon penetration of three $150 \mathrm{~mm}$ intervals are recorded. The number of blows required for the last two intervals are added to give the standard penetration number, $\mathrm{N}$, at that depth. This number is generally referred to as the $\mathrm{N}$ value which was a correction to an average energy ratio of $60 \%\left(\mathrm{~N}_{60}\right)$. SPT was conducted at intervals of $1.5 \mathrm{~m}$. According to Bezgin [11] a correction to average energy ratio of $60 \%\left(\mathrm{~N}_{60}\right)$ is required to SPT $\mathrm{N}$-values because of the greater confinement caused by the increasing overburden pressure. The correction factors used in the study are those proposed by Das [12] to standardize the field penetration number as a function of the input driving energy and its dissipation around the sampler into the surrounding soil.

\subsection{Numerical Modelling}

Numerical analysis of foundation settlement and bearing capacity were performed using a non-linear finite element analysis with a finite element code. Plaxis, which is a finite element method (FEM) software for deformation analysis and modelling of geotechnical problems was used in the study. [10]

\section{RESULTS AND DISCUSSION}

\subsection{Corrected SPT N-Values $\left(\mathrm{N}_{60}\right)$}

The variation of $\mathrm{N}_{60}$ with depth of test is shown in Figure 1. $\mathrm{N}_{60}$ increased with depth having the highest value of 74.97at $3.6 \mathrm{~m}$ boring depth in BH 3 and the lowest value in BH 5.Such high values of $\mathrm{N}_{60}$ are associable to crystalline formations from the basement complex. Details about soil formations in Nigeria can be found in Ola [13]. $\mathrm{N}_{60}$ values are needed for more accurate design analyses and have less variability or scatter due to test method.

\subsection{Bearing Capacity}

Variations of allowable bearing capacity with boring depth are shown in Figures 2 and 3 for BHs 3 and 5 respectively. The results presented herein are for BHs 3 and 5 that respectively has the highest and lowest values of $\mathrm{N}_{60}$.Based on the method proposed by Meyerhof [14] 
and Plaxis, applied foundation pressures in the range of $100-250 \mathrm{kN} / \mathrm{m}^{2}$ were proposed for use in the site under investigation at shallow depths (depths in the range of 0.6 - $3.6 \mathrm{~m})$. Atat et al. [15] suggested an average allowable bearing pressure of $154.78 \mathrm{kN} / \mathrm{m}^{2}$ for shallow foundations in Akwa-Ibom State. Salahudeen, et al. [1] suggested applied foundation pressures in the range of $120-200 \mathrm{kN} / \mathrm{m}^{2}$ at shallow depths (depths in the range of $0.6-3.6 \mathrm{~m}$ ) for South South geopolitical zone. Also, Salahudeen, et al [2] suggested applied foundation pressures in the range of $135-260 \mathrm{kN} / \mathrm{m}^{2}$ at shallow depths (depths in the range of $0.6-3.6 \mathrm{~m}$ ) for South West geopolitical zone. Based on the numerical modelling results, methods proposed by Meyerhof [14] and Peck et al. [16] were found to give good estimations of allowable bearing capacity of foundation.

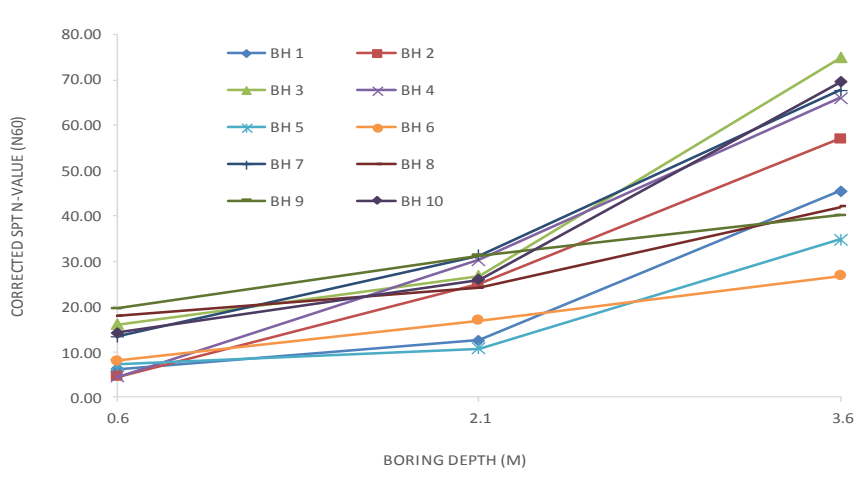

Figure 1: Variation of corrected $N$-values with boring depth

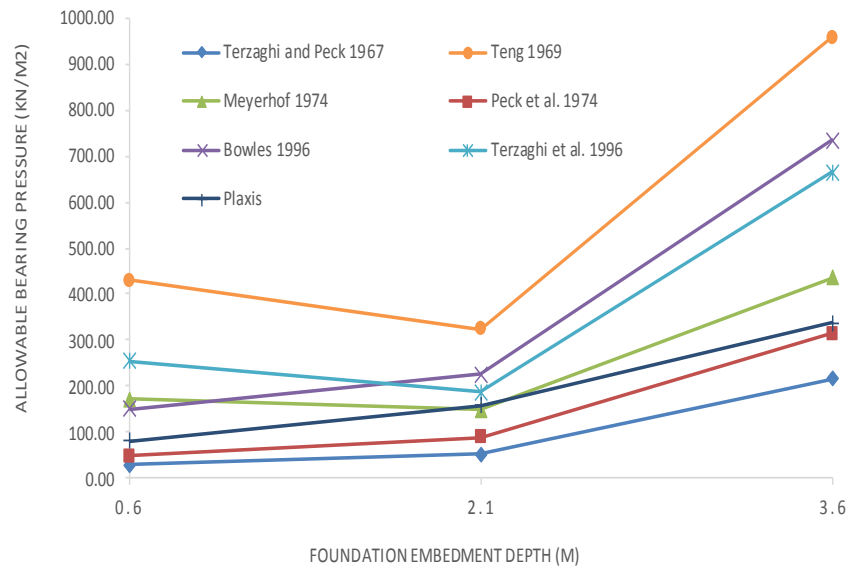

Figure 3: Variation of allowable bearing pressure with foundation embedment depth (BH 5)

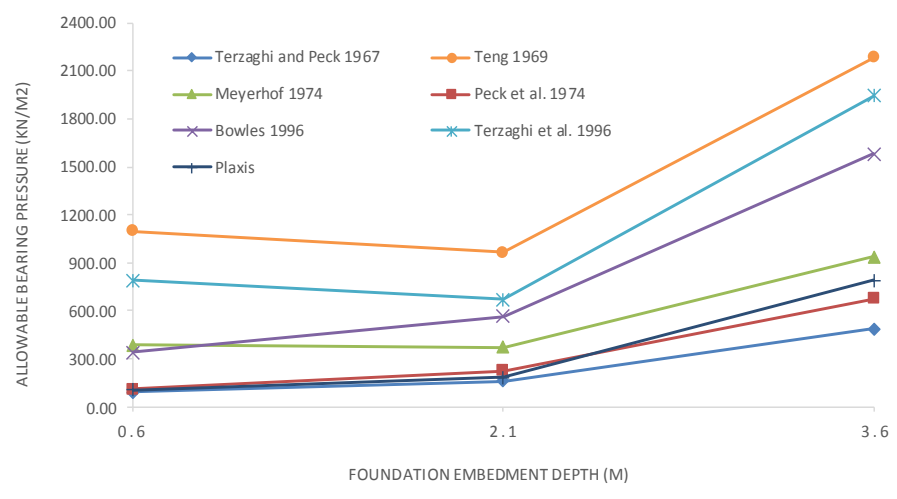

Figure 2: Variation of allowable bearing pressure with foundation embedment depth ( $\mathrm{BH} 3$ )
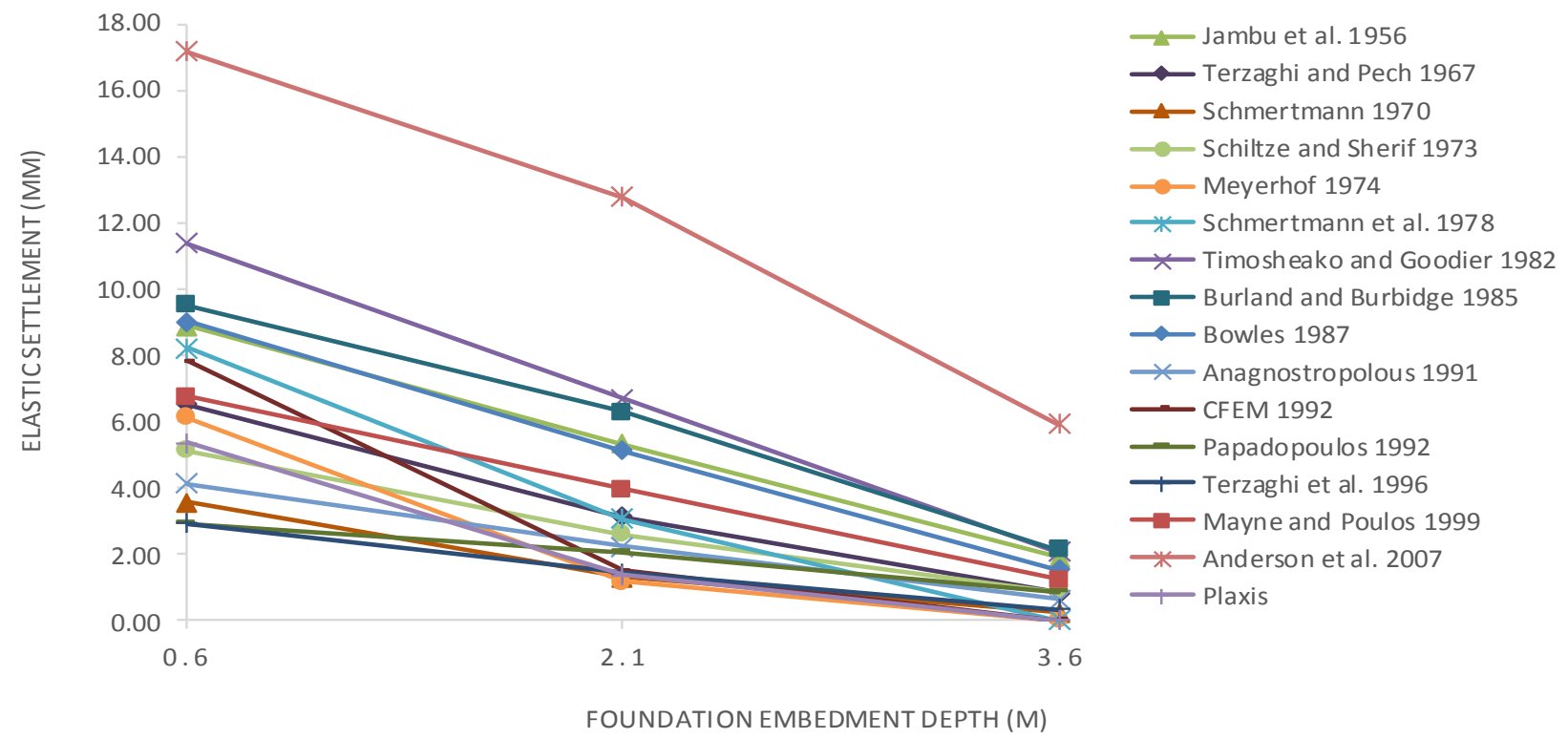

Figure 4: Variation of elastic settlement with foundation embedment depth (BH 3) 


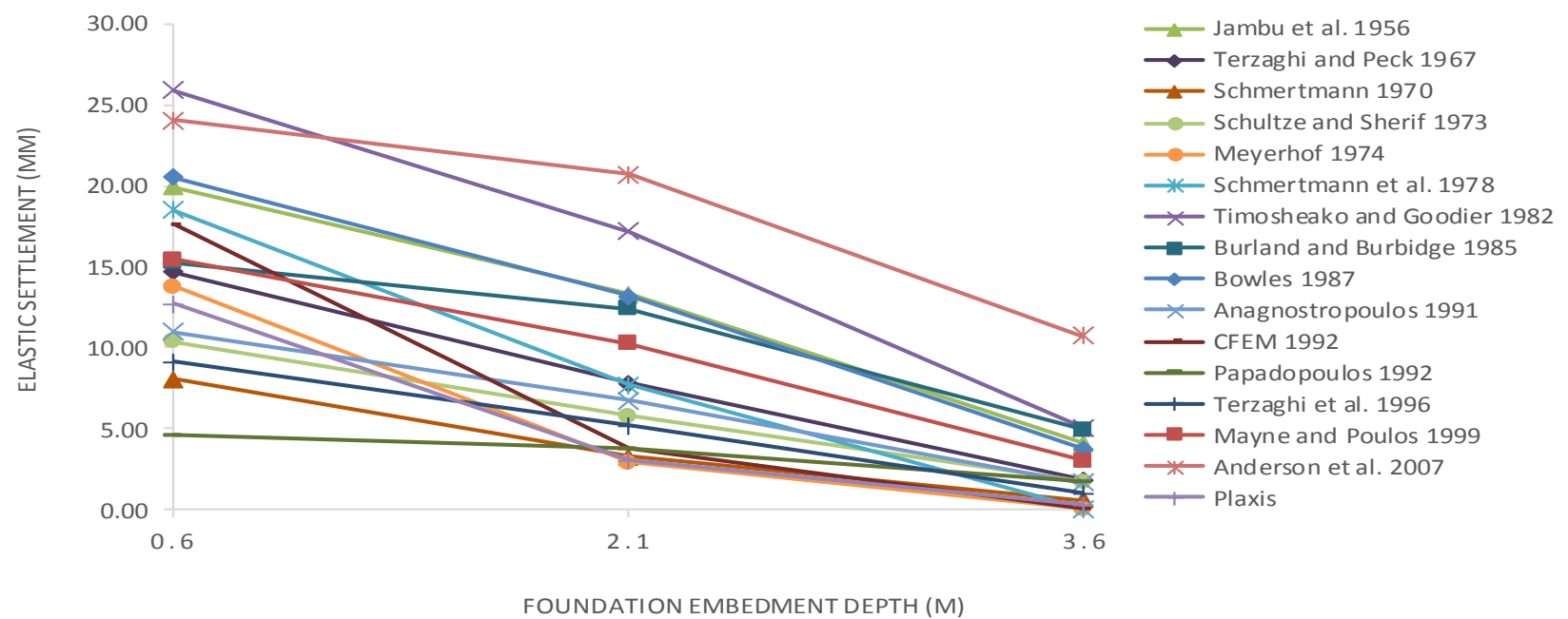

Figure 5: Variation of elastic settlement with foundation embedment depth (BH 5)

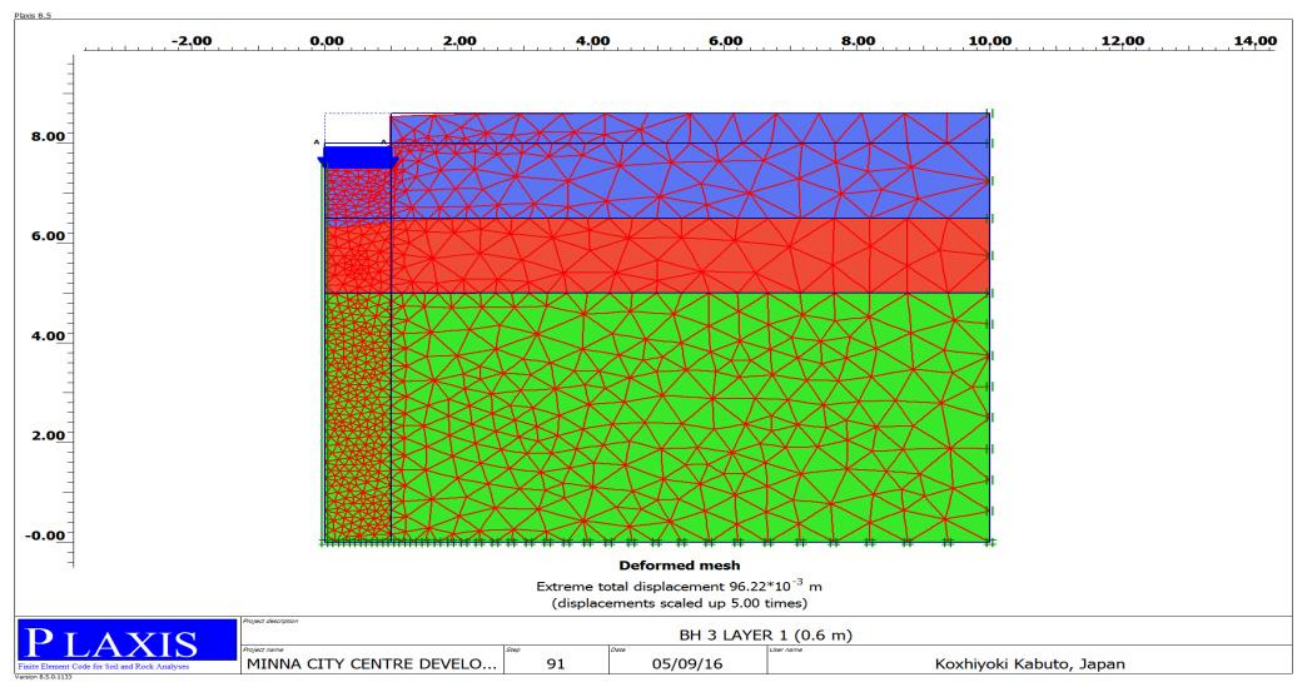

Figure 6: Numerical analysis mesh showing deformation of the soil body at collapse at 0.6 m embedment depth (BH 3)

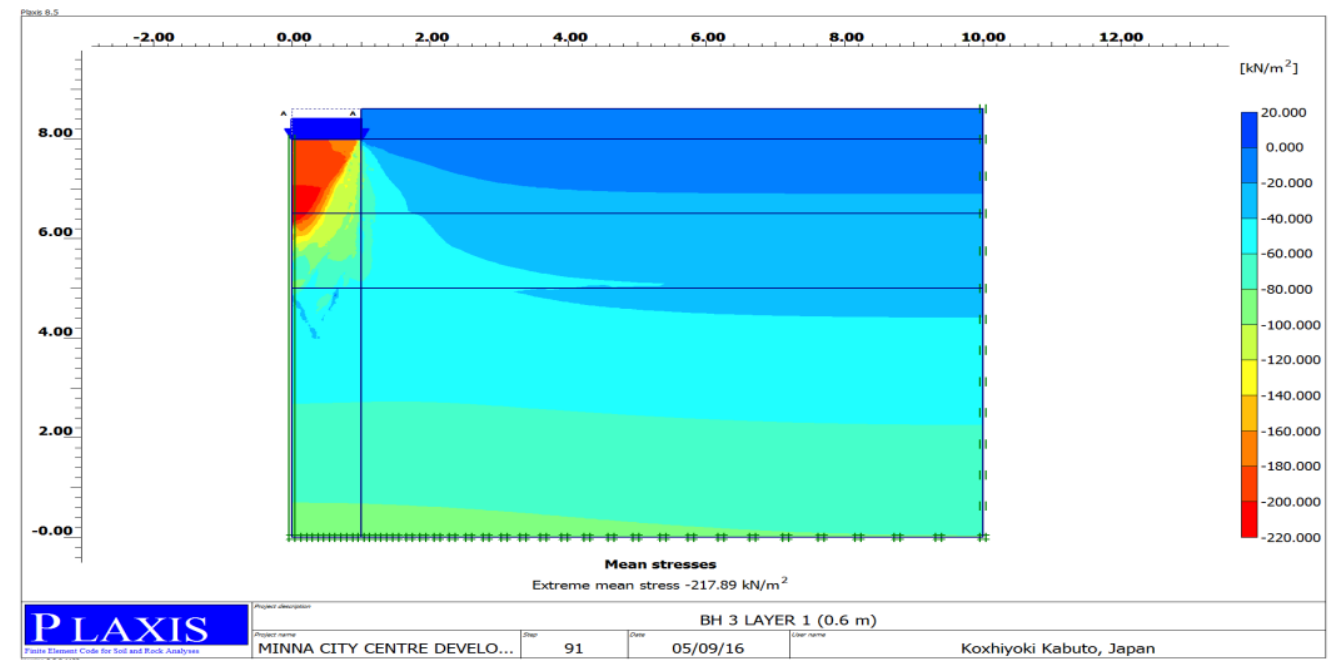

Figure 7: Numerical analysis result of stress distribution up to the collapse of the soil body at $0.6 \mathrm{~m}$ embedment depth (BH 3) 
Investigation of Shallow Foundation Soll Bearing Capacity And Settlement Characteristics ... A. B. Salahudeen \& J. A. Sadeeq

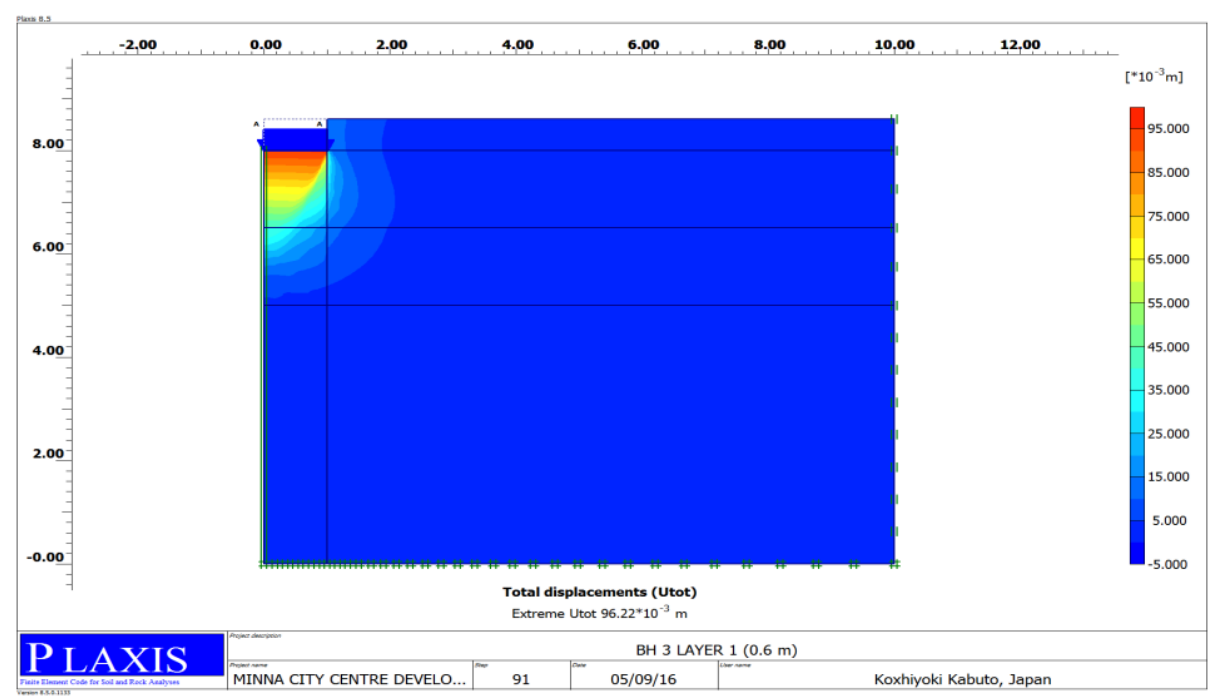

Figure 8: Numerical analysis result of settlement up to the collapse of the soil body at 0.6 m embedment depth (BH 3)

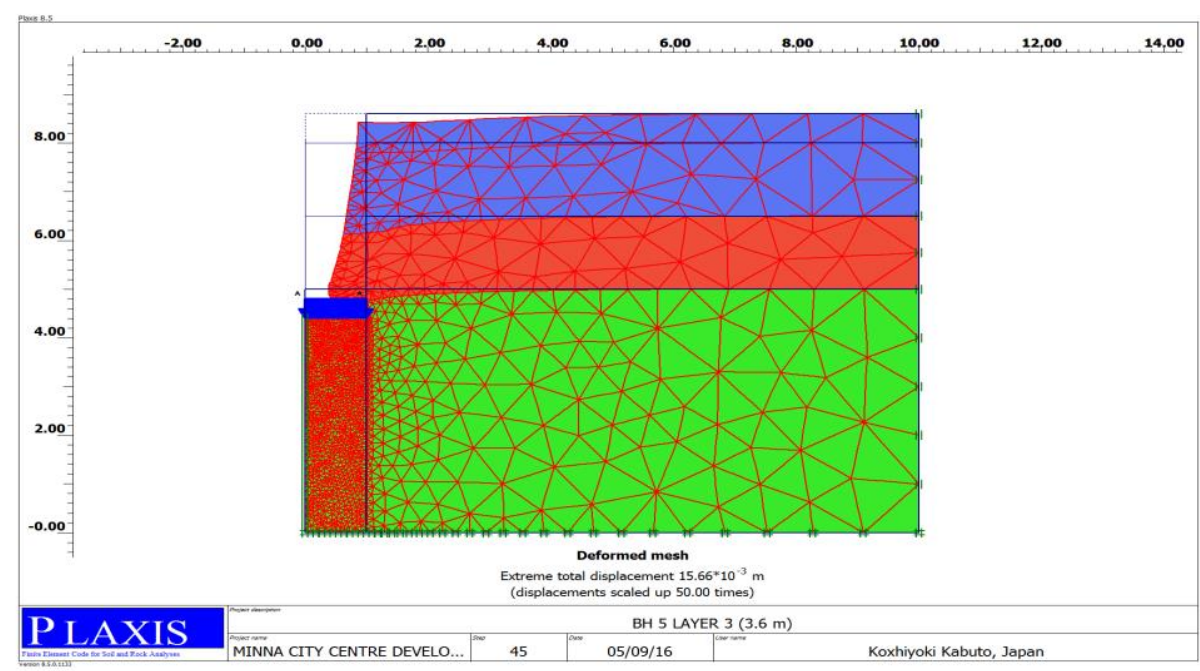

Figure 9: Numerical analysis mesh showing deformation of the soil body at collapse at 3.6 m embedment depth (BH 5)

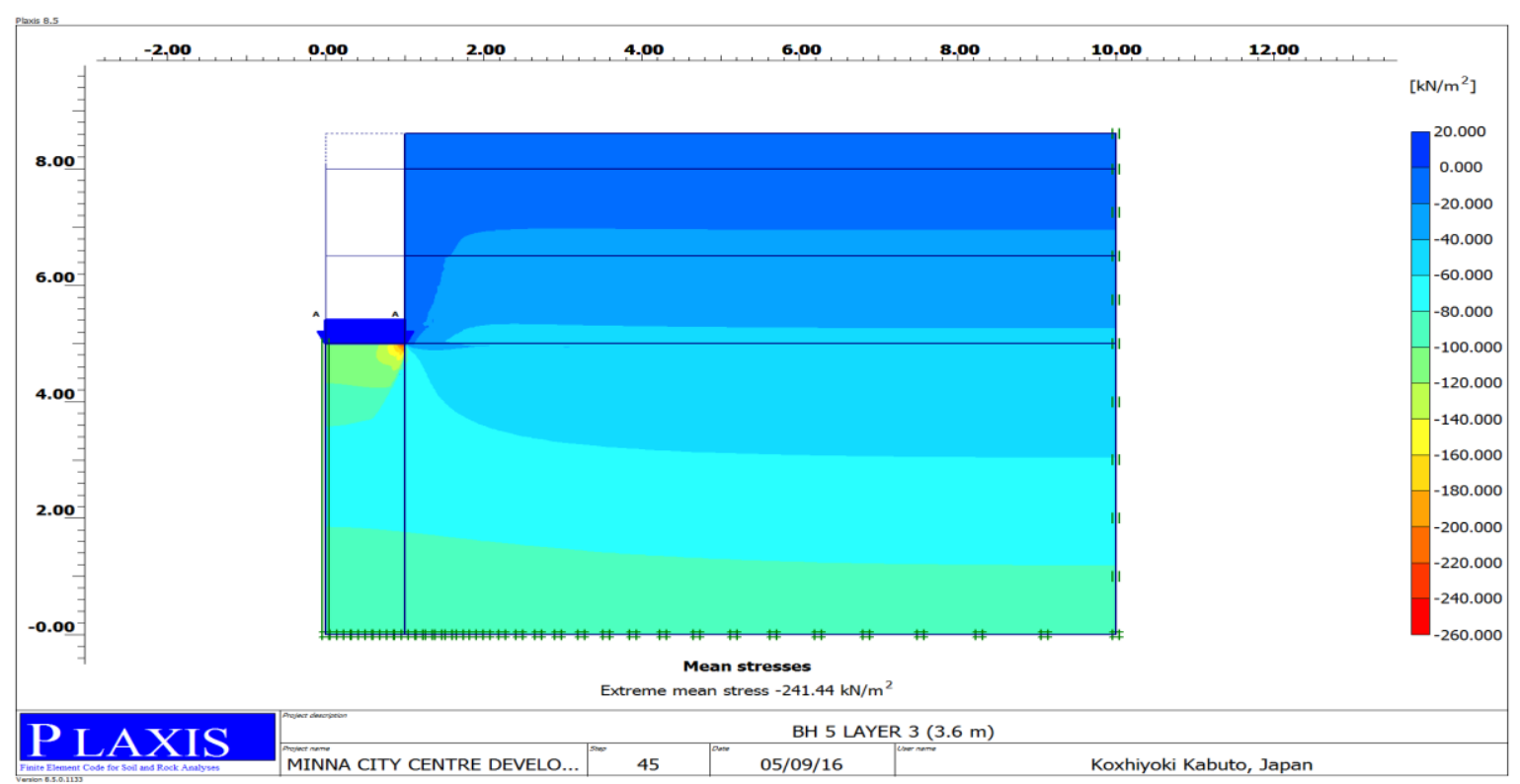

Figure 10: Numerical analysis result of stress distribution up to the collapse of soil body at $3.6 \mathrm{~m}$ embedment depth (BH 5) 


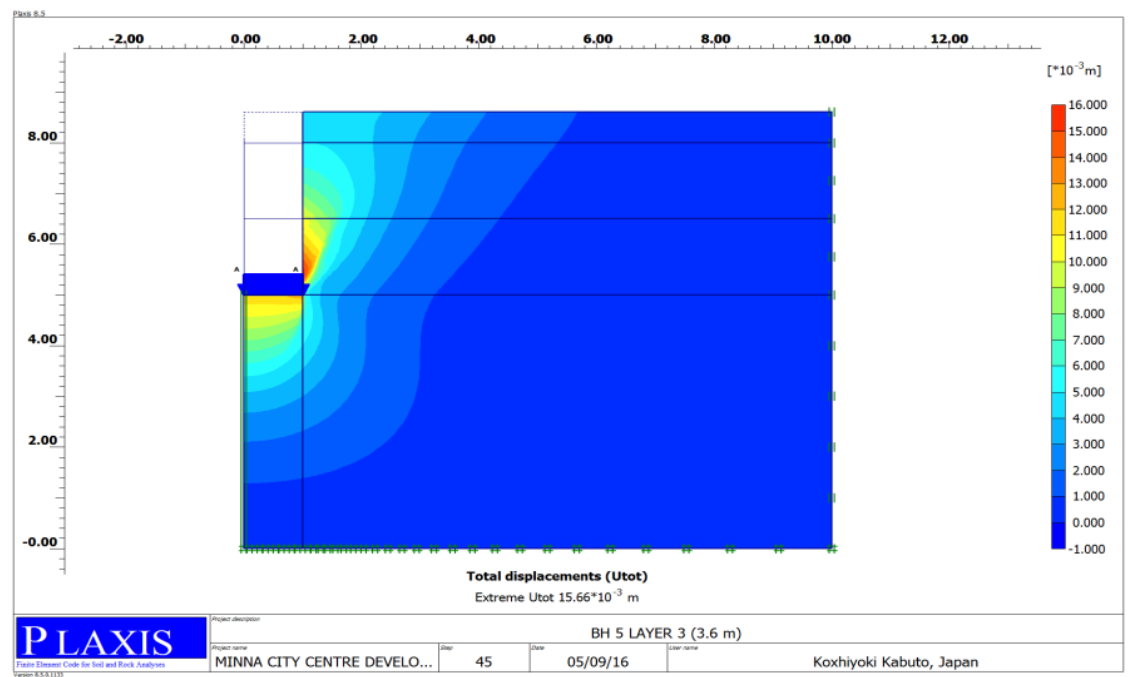

Figure 11: Numerical analysis result of settlement up to the collapse of the soil body at $3.6 \mathrm{~m}$ embedment depth (BH 5)

\subsection{Elastic Settlement of Foundations}

Variations of elastic settlement of foundations with boring depth for various applied pressures are shown in Figures 4 and 5 for BHs 3 and 5 respectively. The figures show the different empirical/analytical models commonly used in computing elastic settlement of shallow foundations. The $\mathrm{N}_{60}$ values indicate that settlement values will be highest in BH 5 due to low $\mathrm{N}_{60}$ values at thatpoint as confirmed in the elastic settlement results. The recorded trend is consistent with observations of reported by Salahudeen et al, [1]. A comparison carried out by Shahin et al. [20] based on field measurement and artificial neural networks (ANN) results among methods proposed by Schmertmann [21], Schltze and Sherif [22] and Meyerhof [23] rated the Schltze and Sherif [22] method as the best for estimating shallow foundation settlements. However, based on the numerical modelling results, comparison of the fifteen empirical/analytical methods considered in this study, showed that the Schltze and Sherif [22],Meyerhof [14], Schmertmann et al [23], Canadian Foundation Engineering Manual (CFEM) [24] as well as the Mayne and Poulos [25] methods gave good estimations of foundation settlement.

The numerical analysis results of soil body deformation, stress distribution and settlement respectively at collapse of the soil body for the at $0.6 \mathrm{~m}$ embedment depth(for BH 3) and $3.6 \mathrm{~m}$ depth (for BH 5)are shown in Figures 6 - 11.

\section{CONCLUSIONS AND RECOMMENDATIONS}

The study considered $\mathrm{N}$-values corrected to the standard average energy of $60 \%\left(\mathrm{~N}_{60}\right)$ as input data in analytical/empirical and numerical models used to predict foundation settlement and bearing capacity for adequate design of Physical structures of the proposed Minna City Centre, at Minna the capital of Niger state.
Based on the results of this study, the following conclusions were made.

a) Allowable bearing pressures of $100-250 \mathrm{kN} / \mathrm{m}^{2}$ at depths between 0.6 and $3.6 \mathrm{~m}$ are adequate for the site.

b) Settlements of footings embedded at depths in the range $0.6-3.6 \mathrm{~m}$ and applied foundation pressures of $50 \mathrm{kN} / \mathrm{m}^{2}$ are within the limiting value of $25 \mathrm{~mm}$ value of allowable total settlement stipulated by Eurocode 7 [33].

c) A comparison of the six empirical/analytical methods considered in this study showed that the Meyerhof [14] and Peck et al. [16] methods gave good estimations of allowable bearing capacity of foundation soils.

d) A comparison of the fifteen empirical/analytical methods considered in this study, showed that the Schltze and Sherif [22], Meyerhof [14], Schmertmannet al. [23], Canadian Foundation Engineering Manual (CFEM) [24] as well as the Mayne and Poulos [25] methods gave good estimations of foundation settlement.

e) Shallow foundations in the investigated site should be placed at a minimum depth of $1.0 \mathrm{~m}$ to avoid excessive settlement.

f) Results of the study can be used for adequate design of light weight structures on the site.

\section{REFERENCES}

[1] Salahudeen, A. B., Ijimdiya, T. S., Eberemu, A. O. and Osinubi, K. J. Prediction of bearing capacity and settlement of foundations using standard penetration data in the South-South geo-political zone of Nigeria, Book of Proceedings, International conference on Construction Summit, Nigerian Building and Road Research Institute (NBRRI), May a,pp. $349-368,2016$. 
[2] Salahudeen, A. B., Eberemu, A. O., Ijimdiya, T. S. and Osinubi, K. J."Prediction of bearing capacity and settlement of foundations in the south-east of Nigeria", Book of Proceedings, Material Science and Technology Society of Nigeria (MSN) Kaduna State Chapter conference, July16, NARICT, Zaria, July 2016b, pp. $15-21$,

[3] Katzenbach, R., Bachmann, G., Ramm, H. “Combined Pile Raft Foundation(CPRF): An Appropriate Solution for Foundation of High-Rise Building." Sloak Journal of Civil Engineering (SJCE) p. 19-29. ,2005,

[4] Salahudeen A. B. and Sadeeq, J. A."Evaluation of bearing capacity and settlement of foundations", Leonardo Electronic Journal of Practices and Technologies (LEJPT), Issue 29, pp. 93-114, 2016.

[5] Das, B. M. and Sivakugan, N. "Settlements of shallow foundations on granular soil: an overview". International Journal of Geotechnical Engineering 19-29, 2007,.

[6] Al-Jabban, M. J. W. "Estimation of Standard Penetration Test (SPT) of Hilla City-Iraq by Using GPS Coordination". Jordan Journal of Civil Engineering (JJCE), Volume 7, No., pp. 133-145. 2, 2013.

[7] Bowles, J.E. Foundation Analysis and Design,

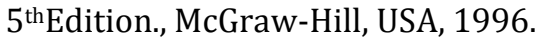

[8] Kulhawy, F.H. and Mayne, P. W. Manual on Estimating Soil Properties for Foundation Design. Eclectic Power Research Institute, Palo Alto, 1990.

[9] American Society for Testing and Materials "Standard Test Method for Penetration Test and Split Barrel Sampling of Soils (D1586-99)". ASTM International, West Conshohocken. 2001.

[10] PLAXIS 2D manual. Plaxis 2D-Version 8 edited by Brinkgreve R. B. J. Delft University of Technology and PLAXIS b.v., The Netherland, 2012.

[11] Bezgin, 0. "An insight into the theoretical background of: Soil structure interaction analysis of deep foundations". A technical report, Istanbul, 2010.

[12] Das, B. M. Principles of Foundation Engineering, SI, Seventh Edition. Cengage Learning. USA, 2011.

[13] Ola, S. A. Tropical Soils of Nigeria in Engineering Practice. A. A, Balkema/Rotterdam Edition, Netherlands, 1983.

[14] Meyerhof, G. G. "Penetration Testing Outside Europe: General Report", Proceedings of the European Symposium on Penetration Testing, Vol. 2.1, pp 40-48. Available from National Swedish Institute for Building Research, P. 0. Box 785, S801-29-GAVLEÄ, Sweden, 1974.

[15] Atat, J. G., Akpabio, I. O. and George, N. J. "Allowable bearing capacity for shallow foundation in Eket Local Government Area, AkwaIbom State, Southern
Nigeria." International Journal of Geosciences, Vol. 4, pp 1491-1500, 2013.

[16] Peck, R. B., Hanson, W. E., and Thornburn, T. H. Foundation Engineering, 2nd edition, Wiley, New York, 1974.

[17] Terzaghi K. and Peck R. B. Soil Mechanics in Engineering Practice, 2nd Ed. John Wiley \& Sons, New York, 1967.

[18] Teng, W.C. Foundation Design. Prentice-Hall Inc., New Jersey, 1969.

[19] Terzaghi, K., Peck, R. B. \& Mesri, G. Soil Mechanics in Engineering Practice. (Third edition).John Wiley \& Sons, New York, 549, 1996.

[20] Shahin, M. A. Jaksa, M. B. and Maier. H. R. "Predicting the settlement of shallow foundations on cohesionless soils using back-propagation neural networks". Research Report R167, University of Adelaide, Department of Civil \&Environmental Engineering, 2000.

[21] Schmertmann, J. H. Static cone to compute static settlement over sand. Journal of Soil Mechanics and Foundations Division ASCE 96(SM3) , 7302-1043, 1970.

[22] Schultze, E. and Sherif, G. "Prediction of settlements from evaluated settlement observations for sand". In Proc., 8th Int. Conf. On Soil Mechanics and Foundation Engineering, Volume 1, No. 3, pp.225$230,1973$.

[23] Schmertmann J. H., Hartman J. P., and Brown P. R. "Improved strain influence factor diagrams". Journal of Geotechnical Engineering, Division, ASCE, Vol. 104 No. 8,pp. 1131-1135, 1978.

[24] Canadian Foundation Engineering Manual. Third edition, BiTech, Publishers Ltd. Richmond, Canada, 1992.

[25] Mayne, P. W. and Poulos, H. G. "Approximate displacement influence factors for elastic shallow foundations". Journal of Geotechnical and Geoenvironmental Engineering, ASCE, Vol. 125 No. 6, 453-460, 1999.

[26] Janbu, N., Bjerrum, L. and Kjaernsli, B. "VeiledningvedLosningav Fundamenteringsoppgaver." Publication 16, Norwegian

Geotechnical Institute, Oslo, 1956, pp. 30-32, 1956.

[27] Timoshenko, S. P. and Goodier, J. N. "Theory of elasticity." Third edition, pp. 398-409, New York, McGraw-Hill, USA, 1982.

[28] Burland, J. B. and Burbidge, M. C. "Settlement of foundations on sand and gravel." Proceedings of Institution of Civil Engineers, Part 1, Vol. 78,pp. 1325-1381. 1985.

[29] Bowles, J. E."Elastic foundation settlement on sand deposits". Journal of Geotechnical Engineering, ASCE, Vol. 113, No. 8, ,pp. 846-860, 1987. 
[30] Anagnostopoulos, A. G., Papadopoulos, B. P. and Kavvadas, M. J. "SPT and compressibility of cohesionless soils." Proceedings of the 2nd European Symposium on Penetration Testing, Amsterdam, 1991.

[31] Papadopoulos, B.P. "Settlements of shallow foundations on cohesionless soils". J. Geotech. Eng., ASCE, Vol. 118, No. 3,pp. 377-393, 1992.

\section{APPENDIX}

Table 1: Empirical/analytical models for soil bearing capacity analysis

\begin{tabular}{lcc}
\hline \multicolumn{1}{c}{ Property } & Model & $\begin{array}{c}\text { Refer } \\
\text { ence }\end{array}$ \\
\hline $\begin{array}{l}\text { Corrected } \\
\text { N-value }\end{array}$ & $N_{60}=\frac{N_{\eta H} \eta_{B} \eta_{S} \eta_{R}}{60}$ & {$[12]$} \\
\hline & $=53\left(\left(N_{1}\right)_{60}-3\right) \frac{(B+0.3)^{2}}{2 B} R_{w} R_{d}$ & {$[18]$} \\
\cline { 2 - 3 } $\begin{array}{l}\text { Allowable } \\
\text { bearing } \\
\text { pressure of } \\
\text { shallow } \\
\text { foundation } \\
\text { s }\end{array}$ & $q_{a}=0.32\left(N_{1}\right)_{60} R_{D} \frac{(B+0.3)^{2}}{B} S_{a}$ & {$[14]$} \\
\cline { 2 - 3 } & $q_{a}=0.44 C_{w}\left(N_{1}\right)_{60} S_{a}$ & {$[16]$} \\
\cline { 2 - 3 } & $q_{a}=0.348\left(N_{1}\right)_{60} R_{D} \frac{(B+0.3)^{2}}{B} S_{a}$ & {$[7]$} \\
\hline
\end{tabular}

Table 2: Empirical/analytical models for elastic settlement analysis

\begin{tabular}{|c|c|c|}
\hline $\begin{array}{l}\mathrm{S} / \\
\mathrm{N}\end{array}$ & Model & Reference \\
\hline 1 & $S_{e}=\mu_{1} \mu_{0} \frac{q^{B}}{E}$ & [26] \\
\hline 2 & $S_{e}=\frac{3 q}{N_{60}}\left(\frac{B}{N_{60}}\right)^{2} C_{W} C_{D}$ & [17] \\
\hline 3 & $S_{e}=C_{1} C_{2} q \sum_{0}^{2 B} \frac{I_{z}}{E_{S}} \Delta z$ & [21] \\
\hline 4 & $S_{e}=\frac{f q \sqrt{B}}{N^{0.87}\left(1+\frac{0.4 D_{f}}{B}\right)}$ & [22] \\
\hline 5 & $S_{e}=\frac{\Delta P B}{2 \Delta \hat{C}_{r}}$ & [14] \\
\hline 6 & $S_{e}=q \sum_{0}^{Z_{1}} \frac{I_{z}}{E_{s}} Z_{1}$ & [23] \\
\hline 7 & $S_{e}=q B \frac{1-\mu^{2}}{E_{s}} I_{S}$ & [27] \\
\hline 8 & $=0.14 \alpha\left(\frac{1.71}{\left(N_{60(a)}\right)^{1.4}}\right)\left(\frac{1.25(L / B)}{0.25+(L / B)}\right)^{2}$ & [28] \\
\hline
\end{tabular}

[32] Anderson B. J., Townsend F. C. and Rahelison L. "Load testing and settlement prediction of shallow foundation."Journal of Geotechnical and Geoenvironmental Engineering, ASCE. Vol. 133, No 12, , pp. 1494-1502, 2007.

[33] Eurocode 7: European Committee for Standardization (CEN).Geotechnical design-Part 1, general rules. Eurocode 7, No.CEN/TC250, Brussels, Belgium, 1994.

\begin{tabular}{ccc}
\hline $\mathrm{S} /$ & Model & Reference \\
\hline $\mathrm{N}$ & $S_{e=} q_{0} \alpha B^{\mathbf{1}}\left(\frac{1-\mu_{s}{ }^{2}}{E_{S}}\right) I_{S} I_{f}$ & {$[29]$} \\
10 & $S_{e=}=\frac{2.37 q^{0.87} B^{0.7}}{N^{1.2}}$ & {$[30]$} \\
11 & $S_{e=} \frac{q_{0} B i_{c}}{E_{S}}$ & {$[24]$} \\
12 & $S_{e=\left(\frac{q B}{E_{s}}\right) f}$ & {$[31]$} \\
13 & $S_{e=} B^{0.75} \frac{1.7}{\hat{\mathbf{N}}_{60}{ }^{1.4}} q$ & {$[19]$} \\
14 & $S_{e=} \frac{q_{0} B_{e} I_{G} I_{F} I_{E}}{E_{0}}\left(1-\mu_{s}{ }^{2}\right)$ & {$[25]$} \\
15 & $S_{e}=\frac{12 q}{N^{\prime}}\left(\frac{B}{B+1}\right)^{2}$ & {$[32]$} \\
\hline
\end{tabular}

Where:

$\mathrm{N}_{60}=$ Corrected standard penetration number for field conditions

$\left(N_{1}\right)_{60}=N_{60}$ correction for overburden pressure

$\mathrm{N}=$ Measured penetration number ( $\mathrm{N}$-value)

$\eta_{\mathrm{H}}=$ Hammer efficiency $(\%)$

$\eta_{\mathrm{B}}=$ Correction for borehole diameter

$\eta_{\mathrm{S}}=$ Sampler correction

$\eta_{\mathrm{R}}=$ Correction for rod length

$\boldsymbol{\sigma}^{1}{ }_{0}=$ Effective overburden pressure in $\mathrm{kN} / \mathrm{m}^{2}$

$\mathrm{P}_{\mathrm{a}}=$ Atmospheric pressure $=100 \mathrm{kN} / \mathrm{m}^{2}$

$\mathrm{E}_{\mathrm{s}}=$ Elastic modulus of soil

$\mu=$ Poisson's ratio of soil

$\mathrm{q}_{\mathrm{n}}=$ Net pressure on the foundation $\left(\mathrm{kN} / \mathrm{m}^{2}\right)$

$\mathrm{Es}=$ Appropriate value of elastic modulus of soil

$$
\left(\mathrm{kN} / \mathrm{m}^{2}\right)
$$

$\mathrm{q}=$ Applied foundation pressure $\left(\mathrm{kN} / \mathrm{m}^{2}\right)$

$\mathrm{S}_{\mathrm{e}}=$ Elastic settlement $(\mathrm{mm})$

$\mathrm{B}=$ Width of foundation $(\mathrm{m})$

$D_{\mathrm{f}}=$ Depth of embedment $(\mathrm{m})$

$\mathrm{B}_{\mathrm{R}}=$ Reference width $=0.3 \mathrm{~m}$

$\mathrm{H}=$ Thickness of the compressible layer $(\mathrm{m})$

$\mathrm{L}=$ Length of foundation (m) 